\title{
GIDA SEÇIM TARZLARINA GÖRE TÜKETİCİLERİN SÜT VE SÜT ÜRÜNLERİ SATIN ALMA DAVRANIŞLARININ İNCELENMESİ: İZMİR İLİ ÖRNEĞİ
}

\author{
Melike Öncül1, Yusuf Sekman $^{2}$, Filiz Kınıklı ${ }^{2 *}$ M. Metin Artukoğlu² \\ ${ }^{1}$ Ecocert Imo Turkey \\ 2Ege Üniversitesi, Ziraat Fakültesi, Tarım Ekonomisi Bölümü, 35100, İzmir, Türkiye
}

Geliş / Received: 28.04.2020; Kabul / Accepted: 14.07.2020; Online bask1 / Published online: 12.10.2020

Öncül, M., Sekman, Y., Kınıklı, F., Artukoğlu, M.M. (2020). Gıda seçim tarzlarına göre tüketicilerin süt ve süt ürünleri satın alma davranışlarının incelenmesi: İzmir ili örneği. GID $A$ (2020) 45(6)1047-1060 doi: 10.15237 /gida.GD20060.

Öncïl, M., Sekman, Y., Kınkll, F., Artukoğlu, M.M. (2020). Examination of consumers' purchasing behaviour of dairy products by food choice styles: a research on milk and dairy products. GIDA (2020) 45(6)1047-1060 doi: 10.15237/gida.GD20060.

\section{ÖZ}

Satın alma davranışı sosyal, kültürel, psikolojik ve kişisel faktörlerden etkilendiğinden dolayı, kişiler homojen özellik göstermemektedirler. Bu çalışmada gıda seçim tarzlarına göre gruplara ayrllan tüketicilerin süt ve süt ürünleri satın alma davranışları incelenmiştir. İzmir ili merkez ilçelerde yapılan anketler ile 300 tüketiciden elde edilen veriler kullanılmıştr. Tüketicilerin gıda seçim tarzlarının belirlenmesi için Gıda Seçimi Soru Formu (Food Choice Questionnaire) kullanılmışıtı. Tüketicileri gruplandırmak amacı ile kümeleme analizi uygulanmış ve tüketiciler üç gruba ayrllmıstır. Araştırma sonuçlarına göre, sağlıklı ve ekonomik tüketicilerin süt ve süt ürünleri harcamalarının daha fazla olduğu görülmüştür. Tüketiciler süt ve süt ürünlerinin ambalajı olmasına dikkat etmekte ve ambalajda son kullanma tarihinin yazmasını önemsemektedirler. Genel olarak süpermarketlerden alışveriş yapan tüketiciler süt ve süt ürünleri satın alırken plansız satın alma eğilimindedirler.

Anahtar kelimeler: Süt tüketimi, Tüketici tercihi, Ambalaj, Plansız satın alma

\section{EXAMINATION OF CONSUMERS' PURCHASING BEHAVIOUR OF DAIRY PRODUCTS BY FOOD CHOICE STYLES: A RESEARCH ON MILK AND DAIRY PRODUCTS}

\begin{abstract}
The behavior of purchasing is affected by the factors of social, cultural, psychological so that people have not shown homogenous specifications. As a result of that different purchasing activities have been realized vary from person to person. In this study, dairy products purchasing behaviours of consumers divided into groups according to food choice styles were investigated. Data were collected from 300 consumers using a Food Choice Questionnaire in the central districts of Izzmir. Cluster analysis was applied. So, consumers divided into three groups to food choice styles. According to research conclusions; healthy and economic consumers spend more on dairy products. Consumers are care about packaging of dairy products and care about best before date. Generally, consumers tend to impulse buying when purchasing dairy products.
\end{abstract}

Keywords: Milk consumption, Consumer preference, Packaging, Impulse buying

\footnotetext{
"Yazışmalardan sorumlu yazar / Corresponding author

(17): filiz.kinikli@ege.edu.tr, $\quad$ (ग): (+90) 2323115890

且: (+90) 2323881862
}

Melike ÖNCÜL; ORCID no: 0000-0002-0771-6170

Yusuf SEKMAN; ORCID no: 0000-0002-2627-7978

Filiz KINIKLI; ORCID no: 0000-0001-8677-0310

M. Metin ARTUKOĞLU; ORCID no: 0000-0003-4800-5209 


\section{GİRIŞ}

Süt ve süt ürünleri, insanların sağlıklı gelişimi için birçok besin maddesini içinde bulundurmasından dolay1, hayatın her evresinde tüketimi önemli yer tutmakta ve en çok ihtiyaç duyulan besin maddeleri arasında yer almaktadır (Çelik, 2002). Bir litre süt, içeriğindeki yă̆, protein ve laktoz miktarlarnna göre ortalama bir kişinin günlük ihtiyaç duyduğu kalori miktarının büyük bir bölümünü karşılamaktadır (Çetinkaya, 2010; Karakaya ve Akbay, 2013). Ülkeler arasinda bir gelişmişlik ölçütü olarak da kullanılan süt ve süt ürünleri tüketimi, sağlıklı ve dengeli beslenen toplumlarda daha yüksektir. Ulusal Süt Konseyi tarafindan hazırlanan 2018 yll süt raporuna göre Türkiye'de y1llı kişi baş1 içme sütü tüketimi yaklaşık 41.5 kg'dır. Bu rakamın gelişmiş ülkelerde 100 kg'n üstüne ç1ktı̆̆1 görülmüştür (USK, 2018). İnsan beslenmesinde önemi büyük olan süt ve süt ürünleri hijyenik koşullarda üretilmediği, saklanmadığ1, işlenmediği ve gerekli kontroller yapılmadığı taktirde insan sağlığı açısından zararlı olabilmektedir. Bu noktada süt ve süt ürünlerinin hijyenik bir şekilde ambalajlanması ve korunması oldukça önemlidir. Çünkü ambalaj hem ürünün korunup saklanması hem de tüketicilere sağlamış olduğu kullanım ve taşıma kolaylı̆̆ açısından önemli bir unsurdur. Türkiye'de üretilen içme sütünün yaklaşık \%92'si UHT olarak piyasaya sürülmektedir (USK, 2018).

Kaliteli ve güvenli gıda tüketimi tüketiciler için hayati bir öneme sahiptir. Özellikle dayanıklillğ düşük olan süt ve süt ürünlerini satın alırken bu durum daha da fazla önem arz etmektedir. Literatürde daha önce yapılan çalışmalar incelendiğinde, tüketicilerin süt ve süt ürünleri tüketimi ile ilgili yapılan pek çok çalışma olduğu görülmüştür ( Yüzbaşı vd., 1999; Andiç vd., 2002; Açıkgözoğlu, 2006; Akbay ve Tiryaki, 2008; Özel, 2008; Tiryaki ve Akbay, 2009; Sütütemiz vd., 2009; Çetinkaya, 2010; Aybek, 2011; Demircan vd., 2011;Karakaya ve Akbay, 2013; Örmeci Kart ve Demircan, 2014; Onurlubaş ve Çakırlar, 2016; Gök vd., 2017). Çeşitli illerde ve süt ve süt ürünleri tüketiminin farklı noktalannı ele alan bu çalışmalar dikkate alındığında, konunun önemi ortaya çıkmaktadır. Ayrıca tüketicilerin süt ve süt ürünleri satın alma davranışlarının incelenmesinin güncel ve gerekli olduğu görülmüştür.
Bu çalısmada gıda seçim tarzlarına göre gruplara ayrılan tüketicilerin süt ve süt ürünleri satın alma davranışlarının incelenmesi amaçlanmıştır. Bununla birlikte tüketicilerin, ambalaj faktörüne verdikleri önem, ambalajlı süt ve süt ürünlerinde bulunmasını önemsedikleri bilgiler ve market alışverişi sırasında plansız satın alma davranışı sergileme durumlarının incelenmesi de çalışmanın amaçları arasında yer almaktadır.

\section{MATERYAL VE YÖNTEM}

Çalışmanın birincil verilerini İzmir ili merkez ilçelerde (Karabağlar, Buca, Bornova, Konak, Karşıyaka, Bayraklı, Çiğli, Gaziemir, Balçova, Narlıdere, Güzelbahçe) yaşayan tüketiciler ile yapılan anketler oluşturmaktadır. İkincil veri kaynaklarını ise, konu ile benzer önceden yapılmış, makale, tez, proje raporları vb. oluşturmaktadır.

Örnek hacmi oransal örnekleme yöntemine göre hesaplanmış ve $\mathrm{N}$ büyüklügündeki sonlu bir ana kitle için belli bir özelliği taşıyanların bilinen veya tahmin edilen oranına (p) göre örnek hacmi formülü aşağıda belirtilmiştir (Newbold, 1995).

$$
n=\frac{N p(1-p)}{(N-1) \sigma_{\hat{p}_{x}}^{2}+p(1-p)}
$$

$\mathrm{n}=$ Örnek hacmi, $\mathrm{N}=$ İzmir ili hane halkı nüfusu, $\mathrm{p}=$ Maksimum örnek hacmine ulaşmak için $\mathrm{p} 0.50$ alınmıştır. $\sigma_{p x}^{2}=$ Oranın varyansı Oransal örnekleme yöntemine göre, örnek hacmi \% 90 güven aralı̆̆ ve \% 5 hata payı esas alınarak 271 olarak hesaplanmıştır. Örnek hacmi 300'e tamamlanmıştur.

Anketler İzmir ili merkez ilçelerde (Karabağlar, Buca, Bornova, Konak, Karşıyaka, Bayraklı, Çiğli, Gaziemir, Balçova, Narlıdere, Güzelbahçe) yapılmıştır. İlçelerin nüfuslarına göre oransal olarak dağıtım yapılarak, her ilçede yer alan büyük marketlerin önlerinde anketler yapılmıştur. Anket sonucu elde edilen veriler SPSS 20 paket program kullanılarak temel tanımlayıcı istatistikler halinde çizelgeler şeklinde özetlenmiştir. Tüketiciler Steptoe ve arkadaşları (1995) tarafindan geliştirilmiş olan gida seçim soru formu (Food Choice Questionnaire, FCQ) kullanilarak gida seçim tarzlarına göre gruplara ayrılmıştr. Gıda tercihlerinin incelenmesi amacıyla geliştirilen 
ölçek, geçerliliği ve güvenilirliği kabul görmüş, uzun yıllardır liteartürde yaygin olarak kullanılmaktadır (Dikmen vd., 2016). Ölçeğin hedef kitleye uygunluğunu test etmek amaciyla faktör analizi kullanılmıştır. Faktör analizi, karşılıklı ilişki içerisinde olan çok sayıdaki değişkenin azaltılarak, daha iyi açıklanabilmesi için birkaç faktöre indirgenmesidir (Hair vd., 2010). Faktör analizi sonucunda öleçeğin ve faktörlerin güvenilir olup olmadığını test etmek amacıyla Güvenilirlik Analizi (Reliability Analysis) kullanılmıştır. Faktör analizi sonuçlarından yararlanarak, tüketicileri gıda seçim tarzlarına göre homojen gruplara ayırmak için kümeleme analizi uygulanmıştr.

Kümeleme analizi, gözlemleri gruplar veya kümeler halinde bir araya getirmek amaciyla kullanılan bir yöntemdir (Malhotra 2010, Hair vd. 2010). Amac1, gözlemleri dikkate alınan değişkenlere bağlı olarak mümkün olduğu kadar homojen kümeler halinde gruplandirmaktır. Kümeleme analizi sonucunda gida seçim tarzlarına göre gruplara ayrilan tüketicilerin sosyodemografik özellikleri, süt ve süt ürünü satın alma davranışları ile plansız satın alma davranışlarını belirlemek amacıyla temel tanımlayıcı istatistikler kullanılmıştır. Kategorik değişkenler için ki-kare testi yapılmıştır. Sürekli değişkenler için Kolmogorov-Smirnov testi ile normal dağılım testi yapılmıştur. Normal dağıllış göstermediği belirlenen değişkenler KruskalWallis testi uygulanarak gruplar arasinda fark olup olmadığ1 incelenmiştir. Kruskal Wallis testi sonucuna göre çıkan farkların post hoc değerlendirmesi SPSS programı yardımı ile ikili karşılaştırmalarla yapılmış ve Bonferroni düzeltmesi ile değerlendirilmiştir. Hata düzeyi 0.05 olarak belirlenmiştir.

\section{ARAŞTIRMA BULGULARI \\ Tüketicilerin Gıda Seçim Tarzlarını Oluşturan Faktörler}

Tüketicilerin gida seçiminde sağlık, masraf, lezzet gibi birçok faktör etkili olmasına rağmen bu faktörleri sistematik olarak değerlendiren net ölçütler bulunmamaktadır. Fakat 1995 yılında Steptoe ve arkadaşları bireylerin gida seçimiyle ilgili bazı ölçütler belirlemek amacıyla çok boyutlu bir yaklaşım geliştirmişlerdir. Böylece Steptoe ve arkadaşları tarafindan geliştirilen 'Gıda Seçim Formu' (Food Choice Questionnaire, FCQ) ile tüketicilerin g1da seçiminde etkili olan birçok faktörün gruplandırılarak yorumlanması daha kolay hale gelmiştir. Tüketicilerin gida seçim tarzları temelini oluşturan faktörleri belirlemek amacıyla faktör analizi kullanılmıştur. Faktör analizinde amaç, karşılıklı ilişki içerisinde olan çok sayıdaki değişkenin azaltılarak, daha iyi açılanabilmesi için birkaç faktöre indirgenmesidir. Böylece birçok ifade yerine, ilişkili ifadeleri temsil eden faktörler ile gerekli açıklamalar yapılır (Hair vd., 2010).

Faktör analizine tabi tutulan 36 ifadeden 5 ifadenin faktör analizi sürecinde, faktör yükünün birden fazla faktörde, birbirine yakın olması vb. nedenlerle analize uygun olmadığ belirlenerek çıkarılmıştır. Son aşamada ise 31 ifade ve 7 faktörün uygun olduğu belirlenmiştir. Faktörler isimlendirilirken, faktörü oluşturan ifadeler ve orijinal ölçekteki faktör isimleri dikkate alınmıştır. İfadeler ve faktörler için güvenirlilik analizi yapılmıs, verilerin oldukça güvenilir olduğuna karar verilmiştir (Cronbach's $\alpha=0.942)$. Açıklanan toplam varyans \%63.89, Kaiser-Meyer-Olkin (KMO) değeri 0.921 ve Bartlett's testi anlamlı bulunmuştur. Tüketicilerin g1da seçim tarzları temelini oluşturan faktörler ve ifadelere ait ortalamalar çizelge 1'de açılanmıştır. Tüketicilerin her bir ifadeye verdikleri önem düzeyi beşli likert ölçeği (1:Kesinlikle önemsiz, 5:Kesinlikle önemli) kullanılarak elde edilmiştir (Çizelge 1).

\section{Gıda Seçim Tarzlarına Göre Tüketici Gruplar1 ve Profilleri}

Tüketicileri gıda seçim tarzlarına göre homojen gruplara ayırmak için kümeleme analizi kullanılmıştır. Kümeleme analizi, birimleri, değişkenler arası benzerlik ya da farklılıklara dayalı olarak hesaplanan bazı ölçülerden yararlanarak homojen gruplara bölmeyi amaçlamaktadır (Özdamar, 2013). Tüketicilerin gida seçim tarzlarını belirlemek amaciyla yapılan faktör analizi sonuçlarından yararlanılarak, hiyerarşik kümeleme analizi yapılmıştır. Hiyerarşik kümeleme analizinde en yaygin kullanilan yöntemlerden biri olan Ward's yöntemi kullanılmış ve küme sayısı belirlenirken 


\section{M. Öncül, Y. Sekman, F. Kınıklı, M.M. Artukoğlu}

dendogramdan yararlanılmıştır. Gıda seçim tarzlarına göre tüketicilerin üç gruba ayrıldıkları

\%45.7'si ikinci grupta ve \%25.7'si üçüncü grupta yer almıstur (Çizelge 2).

görülmüştür. Tüketicilerin \%28.7’si birinci grupta,

Çizelge 1. Tüketicilerin gida seçim tarzları temelini oluşturan faktörler

Table 1. Food choice styles factors

\begin{tabular}{|c|c|c|c|}
\hline $\begin{array}{l}\text { FAKTÖRLER } \\
\text { FACTORS }\end{array}$ & $\begin{array}{l}\text { Ortalama } \\
\text { Mean }\end{array}$ & $\begin{array}{l}\text { Std.Sapma } \\
\text { Std. Deviation }\end{array}$ & $\begin{array}{l}\text { Faktör Yükü } \\
\text { Factor Loading }\end{array}$ \\
\hline \multicolumn{4}{|l|}{ Duygusal Durum $\operatorname{Mood}(\alpha=0.858)$} \\
\hline Beni uyanı/atik tutması Keeps me awake/alert & 3.62 & 1.22 & 0.686 \\
\hline Moralimi düzeltmesi/keyiflendirmesi Cheers me up & 3.95 & 1.18 & 0.674 \\
\hline Stresin üstesinden gelmemde yardımc1 olması Helps me cope with stress & 3.54 & 1.26 & 0.643 \\
\hline Rahatlamama yardımc1 olması Helps me relax & 3.70 & 1.14 & 0.643 \\
\hline Güzel kokması Smells nice & 4.06 & 1.08 & 0.617 \\
\hline Kendimi iyi hissettirmesi Makes me feel good & 3.82 & 1.13 & 0.587 \\
\hline Hoş bir görüntüye sahip olmas1 Looks nice & 3.84 & 1.12 & 0.580 \\
\hline \multicolumn{4}{|l|}{ Aşinalık Familiarity ( $\alpha=0.839$ ) } \\
\hline Hayatla başa çıkmamda yardımc1 olması Helps me to cope with life & 3.52 & 1.25 & 0.693 \\
\hline Genelde yediklerimden olması Is what I usually eat & 3.84 & 1.12 & 0.687 \\
\hline $\begin{array}{l}\text { Hangi ülkeden geldiğinin açıkça belirtilmesi Has the country of origin clearly } \\
\text { marked }\end{array}$ & 3.56 & 1.29 & 0.663 \\
\hline Çocukken yediklerim gibi olması Is like the food I ate when I was a child & 3.58 & 1.32 & 0.600 \\
\hline $\begin{array}{l}\text { Yaşadığım veya çalışı̆̆ım yere yakın marketlerden satın alınabilir olması } \\
\text { Can be bought in shops close to where I live or work }\end{array}$ & 3.92 & 1.10 & 0.582 \\
\hline $\begin{array}{l}\text { Politik olarak onayladığım ülkelerden gelmesi Comes from countries I approve } \\
\text { of politically }\end{array}$ & 3.43 & 1.36 & 0.575 \\
\hline \multicolumn{4}{|c|}{ Sağlık-Kilo Kontrolü Health-Weight control $(\alpha=0.829)$} \\
\hline Yağ oranının düşük olması Is low in fat & 3.58 & 1.28 & 0.748 \\
\hline Kalorisinin düşük olmas1 Is low in calories & 3.38 & 1.38 & 0.673 \\
\hline Katk1 maddesi içermemesi Contains no additives & 4.06 & 1.09 & 0.643 \\
\hline İçeriğinin doğal olması Contains natural ingredients & 4.10 & 1.06 & 0.638 \\
\hline Bilinen olması Is familiar & 3.76 & 1.17 & 0.502 \\
\hline \multicolumn{4}{|l|}{ Fiyat Price $(\alpha=0.712)$} \\
\hline Pahalı olmamas1 Is not expensive & 4.12 & 0.98 & 0.659 \\
\hline Ucuz olması Is cheap & 4.02 & 1.06 & 0.647 \\
\hline Ödeyeceğim paraya değer olması Is good value for money & 4.31 & 0.91 & 0.638 \\
\hline $\begin{array}{l}\text { Marketlerde kolayca bulunabilir olmas1 Is easily available in shops and } \\
\text { supermarkets }\end{array}$ & 3.98 & 1.09 & 0.506 \\
\hline \multicolumn{4}{|l|}{ Doğallık Natural content $(\alpha=0.784)$} \\
\hline Sağlığımı koruması Keeps me bealtby & 4.21 & 0.99 & 0.733 \\
\hline $\begin{array}{l}\text { Cildim dişlerim saçım tırnaklarım vs. için iyi olması Is good for my } \\
\text { skin/teeth/hair/nails etc }\end{array}$ & 4.08 & 1.09 & 0.672 \\
\hline Yapay maddeler içermemesi Contains no artificial ingredients & 3.97 & 1.12 & 0.545 \\
\hline \multicolumn{4}{|l|}{ Besleyicilik Nutritiousness $(\alpha=0.726)$} \\
\hline Besleyici olmas1 Is nutritious & 4.16 & 0.98 & 0.626 \\
\hline Lifi ve kepeği yüksek olmasi Is high in fibre and roughage & 3.49 & 1.28 & 0.556 \\
\hline Proteininin yüksek olması Is high in protein & 3.94 & 1.05 & 0.473 \\
\hline \multicolumn{4}{|l|}{ Elverişlilik - Kolayllk Convenience $(\alpha=0.712)$} \\
\hline Hazırlamasinin kolay olmasi Can be cooked very simply & 3.76 & 1.15 & 0.796 \\
\hline Hazırlamak için zaman almaması Takes no time to prepare & 3.89 & 1.12 & 0.615 \\
\hline Çok kolay pişirilebilir olmasi Can be cooked very simply & 3.77 & 1.12 & 0.478 \\
\hline
\end{tabular}


Çizelge 2. G1da seçim tarzı kümeleme analizi sonuçları Table 2. Cluster analysis results to food choice styles

\begin{tabular}{lccc}
\hline & \multicolumn{3}{c}{ Tüketici Gruplar1 Consumer Groups } \\
\cline { 2 - 4 } & $\begin{array}{l}\text { I.Grup } \\
\text { I.Group }\end{array}$ & $\begin{array}{l}\text { II.Grup } \\
\text { II.Group }\end{array}$ \\
\cline { 2 - 4 } & & Ortalama Mean \\
\hline Duygusal Durum III.Group \\
\hline Aşinalık Familiarity & -0.19906 & -0.17222 & 0.52875 \\
\hline Sağllk-Kilo Kontrolü Health-Weight control & 0.31263 & -0.48215 & 0.50868 \\
\hline Fiyat Price & -0.63173 & 0.00952 & 0.68863 \\
\hline Doğal İçerik Natural content & -0.56634 & 0.21536 & 0.24936 \\
\hline Besleyici Nutritiousness & -0.36950 & 0.47658 & -0.43526 \\
\hline Elverișlilik-Kolayllk Convenience & -0.34654 & -0.02514 & 0.43177 \\
\hline Tüketici Sayls1 Number of consumer & -0.48448 & 0.17134 & 0.23625 \\
\hline Yüzde (\%) Percent & 86 & 137 & 77 \\
\hline
\end{tabular}

Faktör analizi sonuçlarından yararlanılarak, yapilan kümeleme analizi sonucunda tüketiciler üç gruba ayrılmış ve faktör yükleri dikkate alınarak, tüketici profilleri çıarılmıştur. Tüketici grupları isimlendirirken gida seçim tarzları dikkate alınmıștır. Buna göre birinci grupta yer alan tüketicilere "geleneksel tüketiciler" ismi verilmiştir. Bu grupta yer alan tüketiciler, gida satın alırken yeniliklere kapalıdır ve eskiden alışık oldukları tatları tercih ederler. Ayrica kolaylikla satın alabilecekleri yerleri tercih ederler, gidaların menşei de onlar için önemlidir. İkinci grupta yer alan tüketicilere "sağlıklı ve ekonomik tüketiciler" ismi verilmiştir. Çünkü bu grupta yer alan tüketiciler, sağlığına dikkat eden ve doğallıktan yana olan tüketicilerdir. Bunun yanında ürünlerin ekonomik olmasina dikkat edip, kolay bulunabilirliğine önem verirler. Üçüncü grupta yer alan tüketicilere ise "vücut ve zihin sağllğına dikkat eden tüketiciler" ismi verilmiştir. Satın aldıkları gıdalarnn içeriğine dikkat ederler. İçeriğinin doğal olmasının yanında kalori ve yağ oranının düşük olması onlar için önemlidir. Alışık oldukları gidaları tercih eder, yeni ve farklı tatlar denemeye pek açık değildirler. Satın aldıkları gıdaların, görüntüsüne önem verirler. Stresli zamanlarda daha çok alışveriş yapma eğilimdedirler ve satın aldıkları gidaların kendilerini iyi hissettirmesini isterler. Bundan sonra yapılan tüm analizlerde tüketici grupları için bu isimlendirmeler kullanılmıştır.
Gıda Seçim Tarzlarına Göre Tüketicilerin Sosyoekonomik ve Demografik Yapıları

Gıda seçim tarzlarına göre üç gruba ayrılan tüketicilerin sosyodemografik özellikleri çizelge 3'te verilmiştir. Tüketicilerin yaşları incelendiğinde, yaş ortalamasının 37.81 olduğu ve tüm grupların yaşlarının birbirine yakın olduğu dikkat çekmektedir. Gruplar arasında istatistiksel olarak bir fark olmadığı tespit edilmiştir $(P>0.05)$. Görüşülen tüketicilerin \%56'sı kadın, \%44'ü erkektir. Gruplar arasında erkek ve kadın tüketicilerin dağllımı incelendiğinde ise, geleneksel tüketicilerde erkekler daha fazla iken, diğer tüketici gruplarında kadınların oranı daha fazladır. Gruplar arasında istatistiksel olarak fark olduğu da tespit edilmiştir (Person Chi Square 9.049, P $<0.05)$. Tüketicilerin medeni durumlar1 incelendiğinde gruplar arasında benzer bir dağılım olduğu, genel olarak ise tüketicilerin \%43'nün bekâr \%57'sinin evli olduğu belirlenmiştir. Tüketicilerin eğitim düzeyinin genel olarak düşük olmadiğ1 ve gruplar arasında istatistiksel olarak fark olmadığ1 $(P>0.05)$ görülmektedir. Ankete katılan tüketicilerin hane nüfusu ortalama 3.72 kişidir. Evde grda alısverişinden sorumlu olan kişinin genellikle anket yapılan kişiler olduğu tespit edilmiştir. Çalışma süpermarketlerin önünde yapıldığ1 için bu durum beklenen sonuçlardan biri olmuştur. Tüketicilerin ortalama aylık geliri 3763.33 TL, aylık harcamaları 3091.83 TL, g1da harcamalar1 938.56 TL, aylık süt ve süt ürünleri harcamalar1 ise 205.06 TL'dir. Literatürde tüketicilerin g1da ve süt ürünlerine yaptıkları 
harcamaları değerlendiren çalışmalar incelendiğinde gelir gruplarına göre değişmekle birlikte, genel olarak benzer sonuçların olduğu görülmüştür ( Demircan vd., 2011; Karakaya ve Akbay, 2013; Yatağan vd., 2015; Gök vd., 2017). Tüketici gruplarına göre harcama durumu incelendiğinde, sağlıklı ve ekonomik tüketicilerin toplam harcamalar içerisinde gida harcamaları ve gıda harcamaları içerisinde de süt ve süt ürünleri harcamalarının diğer gruptaki tüketicilere göre daha yüksek olduğu görülmektedir. Sağlık konusunda diğer tüketicilere göre daha hassas olan bu tüketicilerin süt ve süt ürünleri için daha fazla harcama yapmaları beklenen bir durumdur. Ayrıca, aylık harcama miktarı diğer gruptaki tüketicilere göre daha düşük olan bu tüketicilerin gıda harcamalarının oranının daha yüksek olması, Sağlıklı beslenmenin yanında ekonomik olmaya da dikkat eden bu tüketiciler için uygun bir davranış olduğu düşünülmektedir (Çizelge 3).

Çizelge 3. Gıda Seçim Tarzlarına Göre Tüketicilerin Sosya-demografik Özellikleri

Table 3. Social-demographic characteristics of consumers to food choice styles

\begin{tabular}{|c|c|c|c|c|}
\hline & $\begin{array}{l}\text { Geleneksel } \\
\text { Tüketiciler } \\
\text { Traditional } \\
\text { consumers }\end{array}$ & $\begin{array}{l}\text { Sağllkli ve } \\
\text { Ekonomik } \\
\text { Tüketiciler } \\
\text { Healtby and } \\
\text { economic } \\
\text { consumers }\end{array}$ & $\begin{array}{l}\text { Vücut ve Zihin } \\
\text { Sağllŏgna Dikkat } \\
\text { eden Tüketiciler } \\
\text { Consumers attentive to } \\
\text { body and mind }\end{array}$ & $\begin{array}{l}\text { Genel } \\
\text { Ort. } \\
\text { General }\end{array}$ \\
\hline Yaş (y1l) Age (year) & 38.08 & 37.93 & 37.30 & 37.81 \\
\hline \multirow[t]{2}{*}{$\begin{array}{l}\text { Cinsiyet (\%)* } \\
\text { Gender }\end{array}$} & 43.0 & 63.5 & 57.1 & 56.00 \\
\hline & 57.0 & 36.5 & 42.9 & 44.00 \\
\hline $\begin{array}{l}\text { Eğitim Düzeyi (y1l) Education } \\
\text { Level (year) }\end{array}$ & 12.91 & 13.08 & 12.45 & 12.87 \\
\hline $\begin{array}{l}\text { Hane nüfusu (sayi) Household } \\
\text { population (count) }\end{array}$ & 3.67 & 3.86 & 3.51 & 3.72 \\
\hline $\begin{array}{l}\text { Ailenin aylik geliri (TL) } \\
\text { Monthly income }\end{array}$ & 4099.42 & 3422.26 & 3994.81 & 3763.33 \\
\hline $\begin{array}{l}\text { Ailenin aylik harcamas1 (TL) a } \\
\text { Monthly expense }\end{array}$ & 3314.53 & 2808.39 & 3347.40 & 3091.83 \\
\hline $\begin{array}{l}\text { Ailenin aylik gida harcamas1 } \\
\text { (TL) Monthly food expense }\end{array}$ & 1016.86 & 891.39 & 935.06 & 938.56 \\
\hline $\begin{array}{l}\text { Ailenin aylik süt ve süt } \\
\text { ürünleri harcamas1 (TL)*c } \\
\text { Monthly dairy products expense }\end{array}$ & 201.92 & 212.04 & 196.17 & 205.06 \\
\hline $\begin{array}{l}\text { Toplam harcamalar içerisinde } \\
\text { gida harcamas1 oran1 }(\%)^{\mathrm{b} / \mathrm{a}} \\
\text { Food expenditure rate in total } \\
\text { expenditure }\end{array}$ & 30.68 & 31.74 & 27.93 & 30.36 \\
\hline $\begin{array}{l}\text { Toplam g1da harcamas1 } \\
\text { içerisinde süt ve süt ürünleri } \\
\text { harcama oranı }(\%) \mathrm{c} / \mathrm{b} \text { Dairy } \\
\text { expenditure rate in total food } \\
\text { expenditure }\end{array}$ & 19.86 & 23.79 & 20.98 & 21.85 \\
\hline
\end{tabular}


Tüketicilerin Süt ve Süt Ürünlerine Yönelik Satın Alma Davranışları

Ankete katılan tüketicilerin genel olarak süt ve süt ürünlerini satın alırken süpermarketleri tercih ettikleri, pazar ve toptancilar1 ise en az tercih ettikleri belirlenmiştir. Tüketici gruplarına göre durum incelendiğinde ise, geleneksel tüketicilerin bakkaldan süt ve süt ürünleri satın alma sıklığının daha fazla olduğu dikkat çekmiştir. Eski alışkanlıklarına bağlı kalmayı tercih eden ve kolaylıkla satın alabilecekleri yerleri tercih eden bu tüketicilerin bakkalı, diğer tüketicilere göre daha çok tercih etmesi şaşırtıcı bir sonuç olmamıştır.

Tüketicilerin süt ve süt ürünleri satın alma sıklığ1 incelendiğinde; en sık satın alınan ürünlerin sırasıyla süt, yoğurt ve peynir olduğu, en az sıklıkta satın alınan süt ürünün ise kaymak olduğu belirlenmiştir. Tüketici gruplarına göre durum incelendiğinde de benzer sonuçlar ile karşlaşılmaktadır. Sağlıklı ve ekonomik tüketicilerin diğer tüketicilerden farklı olarak, tereyağı alma sıklı̆̆1 daha azdır. Tüketici grupları ile tereyağ1 satın alma sıklı̆g 1 arasındaki fark istatistiksel olarak anlamlıdır $(P<0.05)$. Hangi tüketici gruplarının birbirinden farklı olduğunu belirlemek amaciyla pairwise post-hoc testi yapılmıştur. Buna göre; sağliklı ve ekonomi tüketiciler ile vücut ve zihin sağlığına dikkat eden tüketiciler arasında fark olduğu tespit edilmiştir $(P$ $<0.05)$ (Çizelge 4).

Çizelge 4. Tüketicilerin Süt ve Süt Ürünleri Satın Alma Sıklığ1

Table 4. Frequency of consumers to purchase dairy products

\begin{tabular}{|c|c|c|c|c|}
\hline & $\begin{array}{l}\text { Geleneksel } \\
\text { Tüketiciler } \\
\text { Traditional consumers }\end{array}$ & $\begin{array}{l}\text { Sağllkli ve Ekonomik } \\
\text { Tüketiciler Healthy and } \\
\text { economic consumers }\end{array}$ & $\begin{array}{l}\text { Vücut ve Zihin } \\
\text { Sağlluğına Dikkat eden } \\
\text { Tüketiciler Consumers } \\
\text { attentive to body and mind }\end{array}$ & $\begin{array}{l}\text { Genel } \\
\text { Ort. } \\
\text { General }\end{array}$ \\
\hline Süt Milk & 3.22 & 3.29 & 3.04 & 3.21 \\
\hline $\begin{array}{l}\text { Yoğurt } \\
\text { Yogurt }\end{array}$ & 3.23 & 3.19 & 3.04 & 3.16 \\
\hline Peynir Cheese & 2.93 & 2.96 & 2.97 & 2.96 \\
\hline Ayran ayran & 2.88 & 2.64 & 2.78 & 2.75 \\
\hline $\begin{array}{l}\text { Tereyağ1* } \\
\text { butter }\end{array}$ & 2.37 & 2.20 & 2.51 & 2.33 \\
\hline $\begin{array}{l}\text { Kaymak } \\
\text { cream }\end{array}$ & 1.77 & 1.73 & 1.88 & 1.78 \\
\hline
\end{tabular}

1: Hiç 2: Ayda birkaç kez 3: Haftada bir 4: Haftada birkaç kez 5: Her gün

1: Never 2: A few times in a month 3: Once a wee 4: Few times a week 5: Everyday

* Kruskal Wallis testine göre gruplar arasındaki fark $P \leq 0.05$ için anlamlidır.

* According to Kruskal-W allis test, the difference between the groups was found to be significant for $P \leq 0.05$

Tüketicilerin süt ve süt ürünleri satın alırken ambalajlı olmasına dikkat ettikleri ürünlerin başında önemli buldukları 3.68 ortalama ile yoğurt gelmektedir. Bunu 3.66 ortalama ile süt, 3.61 ortalama ile peynir ve 3.49 ortalama ile tereyağ 1 takip etmektedir. Kaymak ise tüketicilerin ambalajlı ürün olmasına orta derece önem verdiğ ürünler arasında yer almaktadır. Tüketici gruplarına göre ambalaj faktörünün önemi incelendiğinde; geleneksel tüketiciler için ambalaj faktörünün diğer tüketicilere göre daha az önemli olduğu dikkat çekmektedir. Vücut ve zihin sağlığına dikkat eden tüketiciler için yoğurdun ambalaj1 diğer süt ürünlerine göre daha önemliyken, diğer tüketiciler için sütün ambalajının daha önemli olduğu belirlenmiştir. Süt, yoğurt ve peynir ürünleri için gruplar arasında istatistiksel olarak anlamlı farkın olduğu tespit edilmiştir. Her üç ürün için de geleneksel tüketiciler ile sağllklı ve ekonomik tüketiciler arasında fark olduğu görülmüştür $\left(\begin{array}{ll}P & <0.05\end{array}\right)$ (Çizelge 5). 
Çizelge 5. Tüketicilerin Süt ve Süt Ürünlerini Satın Alırken Ambalaj Faktörünün Önemi Table 5. The importance of packaging factor when consumers purchase dairy products

\begin{tabular}{lcccc}
\hline & $\begin{array}{c}\text { Geleneksel } \\
\text { Tüketiciler Traditional } \\
\text { consumers }\end{array}$ & $\begin{array}{c}\text { Sağliklive } \\
\text { Ekonomik } \\
\text { Tüketiciler } \\
\text { Healthy and } \\
\text { economic consumers }\end{array}$ & $\begin{array}{c}\text { Vücut ve Zihin } \\
\text { Sağliğ1na Dikkat } \\
\text { eden Tüketiciler } \\
\text { Consumers attentive to } \\
\text { body and mind }\end{array}$ & $\begin{array}{c}\text { Genel Ort. } \\
\text { General }\end{array}$ \\
\hline Yoğurt*Yogurt & 3.34 & 3.88 & 3.71 & 3.68 \\
\hline Süt* Milk & 3.35 & 3.88 & 3.62 & 3.66 \\
\hline Peynir* Cheese & 3.35 & 3.76 & 3.62 & 3.61 \\
\hline Tereyağ1 butter & 3.24 & 3.62 & 3.55 & 3.49 \\
\hline Ayran ayran & 3.33 & 3.46 & 3.40 & 3.08 \\
\hline Kaymak cream & 2.85 & 3.12 & 3.25 & \\
\hline
\end{tabular}

1:Kesinlikle önemsiz, 2: Az önemli, 3: Orta derecede önemli, 4:Önemli, 5:Kesinlikle önemli

1:Not important, 2:Slightly important, 3: Moderately important, 4:Important, 5:Very important

* Kruskal Wallis testine göre gruplar arasındaki fark $P \leq 0.05$ için anlamlidır.

*According to Kruskal-Wallis test, the difference between the groups was found to be significant for $P \leq 0.05$

Tüketicilerin ambalajlı süt ve süt ürünleri tercih etmelerinde önemli olan nedenler incelendiğinde genel olarak üretim ve son kullanma tarihinin etkili olduğu görülmektedir. Vücut ve zihin sağllğına dikkat eden tüketiciler için en etkili neden kalite-fiyat dengesi iken, geleneksel tüketiciler ile sağlıklı ve ekonomik tüketiciler için üretim ve son kullanma tarihinin en etkili olduğu görülmektedir. "Promosyonlu Ürün Olması" ifadesi dışında diğer ifadeler için gruplar arasında istatistiksel olarak anlamlı fark olduğu tespit edilmiştir $(P<0.05)$ (Çizelge 6$)$.

\section{Çizelge 6. Tüketicilerin Ambalajlı Süt ve Süt Ürünleri Tercih Etme Nedenleri}

Table 6. Reasons for consumers prefer packaged dairy products

\begin{tabular}{|c|c|c|c|c|c|}
\hline & $\begin{array}{c}\text { Geleneksel } \\
\text { Tüketiciler } \\
\text { Traditional } \\
\text { consumers }\end{array}$ & $\begin{array}{l}\text { Sağllkli ve } \\
\text { Ekonomik } \\
\text { Tüketiciler } \\
\text { Healtby and } \\
\text { economic } \\
\text { consumers }\end{array}$ & $\begin{array}{l}\text { Vücut ve Zihin } \\
\text { Sağllğına Dikkat } \\
\text { eden Tüketiciler } \\
\text { Consumers attentive } \\
\text { to body and mind }\end{array}$ & $\begin{array}{l}\text { Genel } \\
\text { Ort. } \\
\text { General }\end{array}$ & $\begin{array}{l}\text { Anlamlılık } \\
\text { Düzeyi } \\
\text { Significancy }\end{array}$ \\
\hline $\begin{array}{l}\text { Üretim ve Son Kullanma Tarihi* production and } \\
\text { exp date }\end{array}$ & 3.84 & 4.48 & 4.05 & 4.19 & 0.000 \\
\hline Ürünün tazeliği* freshness & 3.91 & 4.34 & 4.21 & 4.18 & 0.003 \\
\hline Tat-lezzet* taste & 3.83 & 4.31 & 4.21 & 4.14 & 0.002 \\
\hline $\begin{array}{l}\text { Güvenirliliği ve hijyenik ürünler olması* } \\
\text { reliability and hygienically }\end{array}$ & 3.69 & 4.32 & 4.13 & 4.09 & 0.000 \\
\hline Kalite-fiyat dengesi* quality-price balanced & 3.83 & 4.18 & 4.23 & 4.09 & 0.004 \\
\hline $\begin{array}{l}\text { Daha sağlıklı ürünler olması* more bealthy } \\
\text { products }\end{array}$ & 3.70 & 4.15 & 4.19 & 4.03 & 0.001 \\
\hline Fiyat* price & 3.81 & 4.00 & 4.21 & 4.00 & 0.043 \\
\hline Ürünün içeriği* content & 3.57 & 4.11 & 4.04 & 3.94 & 0.000 \\
\hline $\begin{array}{l}\text { Katk1 maddesi içermemesi* Contains no } \\
\text { additives }\end{array}$ & 3.67 & 4.14 & 3.84 & 3.93 & 0.004 \\
\hline Kolay bulunabilirliği* Is easily available & 3.56 & 4.04 & 4.17 & 3.93 & 0.000 \\
\hline Alışkanlık* Familiarity & 3.63 & 3.83 & 4.19 & 3.87 & 0.003 \\
\hline Kullanım kolaylı̆g1* ease of use & 3.53 & 3.80 & 4.05 & 3.79 & 0.005 \\
\hline Markalı Ürün Olması* branded product & 3.66 & 3.69 & 4.05 & 3.77 & 0.017 \\
\hline İndirim kampanyalar1* discount & 3.58 & 3.73 & 4.03 & 3.76 & 0.014 \\
\hline Ürün çeşitliliği* diversity & 3.42 & 3.55 & 4.00 & 3.63 & 0.002 \\
\hline
\end{tabular}


Satın alma davranışları

\begin{tabular}{lcccccc}
\hline $\begin{array}{l}\text { Ambalajin üzerinde üreticiye ait firma } \\
\text { bilgilerinin } \begin{array}{c}\text { olması* } \\
\text { information on the packaging }\end{array}\end{array}$ & 3.36 & 3.53 & 3.84 & 3.56 & 0.048 \\
\hline Taşıma kolaylığ1* ease of handling & & 3.27 & 3.45 & 3.88 & 3.51 & 0.001 \\
\hline Tavsiye edilmesi* recommendation & 3.23 & 3.45 & 3.86 & 3.49 & 0.005 \\
\hline Promosyonlu Ürün Olması Is promotion & 3.50 & 3.36 & 3.69 & 3.49 & 0.118 \\
\hline Reklam* advertising & 3.27 & 3.11 & 3.91 & 3.36 & 0.000 \\
\hline
\end{tabular}

1:Kesinlikle önemsiz, 2: Az önemli, 3: Orta derecede önemli, 4:Önemli, 5:Kesinlikle önemli

1:Not important, 2:Slightly important, 3: Moderately important, 4:Important, 5:Very important

* Kruskal Wallis testine göre gruplar arasındaki fark $P \leq 0.05$ için anlamlıdır.

* According to Kruskal-W allis test, the difference between the groups was found to be significant for $P \leq 0.05$

Tüketicilerin süt ve süt ürünleri ambalajında bulunmasını önemsedikleri bilgiler içerisinde etkili olan faktörler sirasiyla son kullanma tarihi, fiyat ve besin değeridir. Tüketici gruplarına göre incelendiğinde, tüm gruplarda yer alan tüketicilerin en çok önemsediği bilgi son kullanma tarihidir. En az önemsedikleri bilgi ise geleneksel tüketiciler için geri dönüşüm sembolleri iken sağlıklı ve ekonomik tüketiciler ile vücut ve zihin sağlı̆̆ına dikkat eden tüketiciler için kullanım talimatıdır. Tüketicilerin süt ve süt ürünleri ambalajında bulunmasını önemsedikleri bilgiler içerisinde "içindekiler listesi", "son kullanma tarihi”, "besin değeri”, "g1da güvencesi belgelerinin olmas1", "üretim yeri", "filyat" ve "geri dönüşüm sembolleri” için gruplar arasında farklllık istatistiksel olarak anlamlı bulunmuştur. Hangi tüketici gruplarının birbirinden farklı olduğunu belirlemek amaciyla pairwise post-hoc testi yapılmıştır. Buna göre; tüketicilerin süt ve süt ürünleri ambalajında içindekiler listesini önemli bulması açısından yalnızca geleneksel tüketiciler ile sağllklı ve ekonomik tüketiciler $(P<0.05)$ arasında istatistiksel olarak fark vardır. Ambalajda ürünün son kullanma tarihinin bulunmas1 açısından durum incelendiğinde ise geleneksel tüketiciler ile vücut ve zihin sağlığına dikkat eden tüketiciler $(P>0.05)$ arasinda istatistiksel olarak fark yoktur. Fakat geleneksel tüketiciler ile sağlıklı ve ekonomik tüketiciler $(P<0.05)$ arasinda ve vücut ve zihin sağlığına dikkat eden tüketiciler ile sağlıklı ve ekonomik tüketiciler $(P<0.05)$ arasında istatistiksel olarak anlamlı farkın olduğu görülmüştür. Besin değerine göre durum incelendiğinde geleneksel tüketiciler ile sağlıklı ve ekonomik tüketiciler $\left(\begin{array}{ll}P & <0.05\end{array}\right)$ arasında, geleneksel tüketiciler ile vücut ve zihin sağlığına dikkat eden tüketiciler $\left(\begin{array}{ll}P & <0.05\end{array}\right)$ arasinda istatistiksel olarak anlamlı fark vardır. Gida güvencesi belgelerinin olmasina geleneksel tüketiciler diğer tüketicilere göre daha az önem vermektedir. Geleneksel tüketiciler ile sağlıklı ve ekonomik tüketiciler $\left(\begin{array}{ll}P & <0.05\end{array}\right)$ arasinda istatistiksel olarak fark olmasına rağmen, diğer gruplar arasında fark yoktur. Süt ve süt ürünleri ambalajında üretim yerinin yazması, vücut ve zihin sağllğına dikkat eden tüketiciler için geleneksel tüketicilere göre daha önemlidir. Bu iki grup tüketici arasında $(P<0.05) \quad$ istatistiksel olarak fark olduğu, diğer tüketici grupları arasında ise fark olmadığı belirlenmiştir. Ambalajda fiyat bilgisinin olmasını en az önemseyen tüketiciler geleneksellerdir. Geleneksel tüketiciler ile sağlıklı ve ekonomik tüketiciler $(P<0.05)$ arasinda, geleneksel tüketiciler ile vücut ve zihin sağlığına dikkat eden tüketiciler $(P<0.05)$ arasında istatistiksel olarak anlamlı fark vardır. $\mathrm{Bu}$ üç tüketici grubu arasından fiyat bilgisine en çok önem veren tüketicilerin sağlıklı ve ekonomik tüketiciler olması, bu tüketici profiline uygun bir davranıştr. Çünkü bu grupta yer alan tüketiciler sağlığa verdikleri önemin yanında, satın alacakları ürünlerin, pahalı olmamasina ve ödeyecekleri paraya değer olmasına dikkat etmektedirler. Geri dönüşüm sembollerinin ambalaj üzerinde olmasina en fazla önem veren vücut ve zihin sağlığına dikkat eden tüketicilerdir. Geleneksel tüketiciler ise ambalajda bu sembollerin varlığna diğer bilgiler ve diğer tüketiciler kadar önem vermemektedir. Geleneksel tüketiciler ile vücut ve zihin sağllğına dikkat eden tüketiciler $(P<0.05)$ arasında istatistiksel olarak anlamlı farkın olduğu, diğer tüketici grupları arasında ise fark olmadığ1 tespit edilmiştir (Çizelge 7). 
Çizelge 7. Tüketicilerin Ambalajlı Süt ve Süt Ürünlerinin Ambalajında Bulunmasını Önemsedikleri Bilgiler

Table 7. Information that consumers care about on the packaging of packed dairy products

\begin{tabular}{|c|c|c|c|c|c|}
\hline & $\begin{array}{c}\text { Geleneksel } \\
\text { Tüketiciler } \\
\text { Traditional } \\
\text { consumers }\end{array}$ & $\begin{array}{l}\text { Sağliklı ve } \\
\text { Ekonomik } \\
\text { Tüketiciler } \\
\text { Healthy and } \\
\text { economic } \\
\text { consumers }\end{array}$ & $\begin{array}{l}\text { Vücut ve Zihin } \\
\text { Sağliğına } \\
\text { Dikkat eden } \\
\text { Tüketiciler } \\
\text { Consumers } \\
\text { attentive to body } \\
\text { and mind }\end{array}$ & $\begin{array}{l}\text { Genel } \\
\text { Ort. } \\
\text { General }\end{array}$ & $\begin{array}{l}\text { Anlamlilik } \\
\text { Düzeyi } \\
\text { Significancy }\end{array}$ \\
\hline Son kullanma tarihi* exp date & 4.05 & 4.69 & 4.22 & 4.38 & 0.000 \\
\hline Fiyat* price & 3.64 & 4.18 & 4.08 & 4.00 & 0.001 \\
\hline Besin değeri* nutritive value & 3.60 & 4.13 & 4.16 & 3.99 & 0.000 \\
\hline İçindekiler listesi $*$ content list & 3.71 & 4.10 & 3.96 & 3.95 & 0.042 \\
\hline $\begin{array}{l}\text { G1da güvencesi belgelerinin } \\
\text { olmas1* food safety documents }\end{array}$ & 3.71 & 4.05 & 4.05 & 3.95 & 0.028 \\
\hline Ürünün gramaj1 weight in grams & 3.49 & 3.78 & 3.83 & 3.71 & 0.078 \\
\hline $\begin{array}{l}\text { Üretici bilgileri manufacturer } \\
\text { firms information }\end{array}$ & 3.47 & 3.77 & 3.86 & 3.70 & 0.066 \\
\hline Üretim yeri* the place of production & 3.36 & 3.67 & 3.96 & 3.65 & 0.006 \\
\hline $\begin{array}{l}\text { Geri dönüşüm sembolleri* } \\
\text { recycling symbols }\end{array}$ & 3.27 & 3.63 & 3.75 & 3.56 & 0.031 \\
\hline Kullanma talimatı user manual & 3.28 & 3.47 & 3.73 & 3.48 & 0.067 \\
\hline
\end{tabular}

1:Kesinlikle önemsiz, 2: Az önemli, 3: Orta derecede önemli, 4:Önemli, 5:Kesinlikle önemli

1:Not important, 2:Slightly important, 3: Moderately important, 4:Important, 5:V ery important

* Kruskal Wallis testine göre gruplar arasındaki fark $P \leq 0.05$ için anlamlidir.

* According to Kruskal-Wallis test, the difference between the groups was found to be significant for $P \leq 0.05$

Tüketicilerin Plansız Süt ve Süt Ürünleri Satın Alma Davranışları

1950’li yıllardan beri tüketici davranışları üzerine yapılan araştırmalarda, özellikle pazarlama alanında faaliyet gösteren araştırmacılar, plansız satın alma kavramını incelemektedir (Akagün Ergin ve Özdemir Akbay, 2011). Plansız satın alma davranış1, tüketicinin daha önce herhangi bir plana dahil olmadan bir anda ortaya çıan bir güdünün gerçekleşmesi ile olan satın almalardır (Özgüven Tayfun, 2015). Zuckerman (2000), plansız satın alma davranışında en etkili faktörlerin yenilikleri denemek, yeni ürünleri tüketmek ve bunları kullanmaya yönelik güdüler olduğunu belirtmiştir (Zuckerman, 2000).

Araştırma kapsamında görüşülen tüketicilerin süt ve süt ürünleri satın alırken plansız satın alma yapıp yapmadıkları sorulmuştur. Tüketicilerin $\% 30.7$ 'si plansız satın alma davranışı sergilediğini, \%24'ü plansız satın alma yapmadığını ve \%45.3'ü bazen plansız bir şekilde süt ve süt ürünü sattn aldıklarını ifade etmişlerdir. Özgüven Tayfun
(2015) tarafindan market alıșverişlerinde plansız satın alma davranıșını inceleyen bir çalıșmada, tüketicilerin yaklaşık \%63'ünün plansız satın alma yaptığ1 belirlenmiştir. Giyim ve gida kategorilerinde tüketicilerin plansız satın alma davranışını inceleyen bir başka araşturmada da benzer olarak tüketicilerin yaklaşık \%75'inin plansız satın alma davranışı gösterdiği tespit edilmiştir (Akagün Ergin ve Özdemir Akbay, 2011). Yapılan bu çalışmalarda, görüşülen tüketicilerin $\% 63$ ve $\% 75$ gibi büyük çoğunluğunun plansız satın alma yaptı̆̆ görülmektedir. Araştırma kapsamında görüşülen tüketicilerin ise süt ve süt ürünleri satın alırken yalnızca \%30.7'sinin plansız satın alma davranışı göstermesi, tüketicilerin özellikle süt ve süt ürünlerinde, diğer ürünlere göre daha seçici olduğunu ve ihtiyaçlan dahilinde satın aldıklarını göstermektedir. Tüketici gruplarına göre inceleme yapıldığında, geleneksel tüketicilerin diğer tüketicilere göre plansız satın alma yapmama oranının daha fazla olduğu görülmüştür. Geleneksel tüketiciler gıda satın alırken yeniliklere 
kapalı olarak tanımlanmışt ve bu davranışın bu tüketici profili için uygun olduğu görülmüştür.

Süt ve süt ürünleri satın alırken plansız satın alma yapan ve bazen yaptığını söyleyen tüketicilere, plansiz satı alma siklıkları sorulmuştur. Tüketicilerin $\% 9.3$ 'ü her alışverişte plansız satın alma yaptığını, \%22.7'si sıklıkla, \%22.7'si bazen, \%21.3'ü nadiren, \%24'ü ise nerdeyse hiç plansız satın alma yapmadığını söylemiştir. Tüketici gruplan incelendiğinde birbirine benzer sonuçlar ile karşılaşılmışır.

Plansız süt ve süt ürünü satın alma yaptğıını belirten tüketicilere, bunun nedenleri sorulmuştur. Tüketiciler genel olarak, ürünü görünce ihtiyac1 olduğunu düşünmesi ve fiyat indirimi olmasi nedenleri ile plansız satı alma yaptıklarını belirtmişlerdir. Mağaza atmosferi ve satış elemanının sunumu ise tüketicileri plansız satın alma yapmaya iten en az etkili nedenler arasındadır. Tüketici gruplarına göre durum incelendiğinde, fiyat indiriminin olması geleneksel tüketiciler için diğer nedenlere göre daha önemlidir. Ürünü görünce ihtiyaç duyma fikri ise vücut ve zihin sağllğına dikkat eden tüketiciler ile sağlıklı ve ekonomik tüketiciler için daha etkili bir nedendir. Tüketici gruplar1 ile "ürünü görünce ihtiyacım olduğunu düşünmem" ifadesi arasında istatistiksel olarak fark vardır. Fark olan gruplara bakıldığında ise geleneksel tüketiciler ile sağlıklı ve ekonomik tüketiciler $(P<0.05)$ arasında fark olduğu görülmüştür. Sağllklı ve ekonomik tüketiciler için plansız bir şekilde süt ve süt ürünü satın almayı ürünü görünce ihtiyaç duyma, fiyat indirimi ve promosyon diğer tüketicilere göre daha çok etkili nedenlerdir (Çizelge 8).

Çizelge 8. Tüketicilerin Plansız Süt ve Süt Ürünleri Satın Alma Nedenleri Table 8. Reasons for consumers to impulse buying dairy products

\begin{tabular}{|c|c|c|c|c|c|}
\hline & $\begin{array}{l}\text { Geleneksel } \\
\text { Tüketiciler } \\
\text { Traditional } \\
\text { consumers }\end{array}$ & $\begin{array}{l}\text { Sağliklı ve } \\
\text { Ekonomik } \\
\text { Tüketiciler } \\
\text { Healthy and } \\
\text { economic } \\
\text { consumers }\end{array}$ & $\begin{array}{l}\text { Vücut ve } \\
\text { Zihin } \\
\text { Sağliğına } \\
\text { Dikkat eden } \\
\text { Tüketiciler } \\
\text { Consumers } \\
\text { attentive to body } \\
\text { and mind }\end{array}$ & $\begin{array}{l}\text { Genel } \\
\text { Ort. } \\
\text { General }\end{array}$ & $\begin{array}{l}\text { Anlamlilık } \\
\text { Düzeyi } \\
\text { Significancy }\end{array}$ \\
\hline $\begin{array}{l}\text { Ürünü görünce ihtiyaç olduğunu } \\
\text { düşünmem* thinking that you need } \\
\text { it when seeing }\end{array}$ & 3.16 & 4.00 & 3.55 & 3.66 & 0.000 \\
\hline Fiyat İndirimi olmas1 discount & 3.35 & 3.74 & 3.36 & 3.54 & 0.055 \\
\hline Promosyon olmas1 promotion & 3.10 & 3.31 & 3.00 & 3.17 & 0.364 \\
\hline Ürünü Görünce Beğenme liking & 2.89 & 3.07 & 3.21 & 3.05 & 0.506 \\
\hline $\begin{array}{l}\text { Alışverişe birlikte çıtığım } \\
\text { insanların etkisi The effect of people I } \\
\text { go shopping with }\end{array}$ & 2.73 & 2.83 & 2.95 & 2.83 & 0.704 \\
\hline $\begin{array}{l}\text { Satış Elemanının Etkili Sunumu } \\
\text { Effective Presentation of the } \\
\text { Salesperson }\end{array}$ & 2.75 & 2.44 & 2.64 & 2.58 & 0.377 \\
\hline $\begin{array}{lll}\text { Mağaza } & \text { Atmosferi market } \\
\text { atmosphere } & & \\
\end{array}$ & 2.49 & 2.36 & 2.62 & 2.42 & 0.392 \\
\hline Diğger faktörler others & 2.16 & 2.12 & 1.95 & 2.09 & 0.498 \\
\hline
\end{tabular}

1:Kesinlikle önemsiz, 2: Az önemli, 3: Orta derecede önemli, 4:Önemli, 5:Kesinlikle önemli

1:Not important, 2:Slightly important, 3: Moderately important, 4:Important, 5:V ery important

* Kruskal Wallis testine göre gruplar arasındaki fark $P \leq 0.01$ için anlamlıdır.

* According to Kruskal-W allis test, the difference between the groups was found to be significant for $P \leq 0.01$ 


\section{SONUÇ}

Tüketicilerin gıda seçimini etkileyen çok sayıda faktör olmasına rağmen bunları bazı özelliklere göre gruplandırmak, yorum yapma açısından kolaylık sağlamaktadır. Bu çalışmada tüketiciler gıda seçim tarzlarına göre geleneksel, sağlıklı ve ekonomik, vücut ve zihin sağllğına dikkat eden tüketiciler olma üzere üç gruba ayrılmışlardır.

Süt ve süt ürünleri satın alma davranışını inceleyen bu çalışmada tüketicilerin genel olarak süt ve süt ürünlerini süpermarketlerden satın aldıkları görülmüştür. Tüketiciler için süt, yoğurt ve peynirin ambalajlı olması diğer süt ürünlerine göre daha büyük önem arz etmektedir. Tüketiciler ambalajlı süt ve süt ürünleri tercih etmelerinde en etkili nedenin üretim ve son kullanma tarihi olduğunu belirtmişlerdir. Süt ve süt ürünleri ambalajinda son kullanma tarihinin yazması tüketiciler için en önemli neden iken, kullanım talimatı tüketicilerin en az önemsedikleri bilgiler arasındadır. Tüketici grupları incelendiğinde, geleneksel tüketiciler diğer tüketicilere göre ambalaj üzerindeki bilgileri daha az önemsemektedirler. $\mathrm{Bu}$ tüketiciler genellikle yenililere açık olmadıkları ve eski alışkanlıklarına devam ettikleri için ürünün ambalajı onlar için pek önemli değildir. Genellikle aynı yerlerden ve aynı ürünleri satın almaktadırlar. Bu tüketicilere yeni bir ürünü benimsetmek zorudur. Vücut ve zihin sağlı̆̆ına dikkat eden tüketiciler, süt ve süt ürünleri ambalajında ürünün gramaj1, üretici bilgileri ve üretim yerinin yazmasını diğer tüketicilere göre daha fazla önemsemektedirler. $\mathrm{Bu}$ tüketiciler için ambalaj üzerindeki bilgiler önemlidir. Çünkü satın alma gerçekleştirirken, ürünün görüntüsünün yanında içeriğine dikkat ederler. Kilo kontrolü veya sağlık nedeniyle, ürünün içeriğini dikkatle inceler ve satın aldıkları ürünün kendilerini ruhsal açıdan iyi hissettirmesini isterler. Kendileri için en uygun ürünü bulan bu tüketiciler, kolay kolay farklı ürünler denemeye cesaret edemezler. Bu tarz tüketicilerde marka bağlllığının daha fazla olduğu söylenebilir.

Araştırma kapsamında görüşülen tüm tüketicilerin plansız satın alma eğiliminde olduğu görülmüştür. Tüketicilerin yalnızca $\% 24$ 'ü süt ve süt ürünlerinde plansız satın alma gerçekleştirmediğini söylemiştir. Plansız satın alma yapan ve bazen yaptığını söyleyen tüketicilerin ise bunu yapma sıklı̆ının düşük olduğu görülmüștür. Tüketiciler genellikle, ürünü gördüğü zaman ihtiyacı olduğuna karar verirse plansız satın alma gerçekleştirmektedirler. Geleneksel tüketiciler ise fiyat indirimi olduğu zaman daha fazla satın alma eğiliminde olmaktadır. Duygusal olarak daha hassas olan vücut ve zihin sağllğına dikkat eden tüketiciler, diğer tüketicilere göre, alışverişe birlikte çıktkları kişinin ektisinde kalarak daha fazla plansız satın alma yapmaktadırlar. Sağlıklı ve ekonomik tüketiciler ise fiyat indirimi ve promosyon olmas1 halinde plansız bir şekilde süt ve süt ürünü satın almaktadırlar. İndirim ve promosyon gibi avantajları kaçırmak istemeyen bu tüketiciler her ne kadar ekonomik olmaya dikkat etseler de bu tarz avantajlanı kaçırmak istemeyip, ihtiyacından daha fazla ürün sattn alabilirler.

Ekonomik, sosyal veya psikolojik açıdan farklı olmalarına rağmen tüm tüketiciler süt ve süt ürünleri satın almaktadırlar. Tüketicilerin geçmiş deneyimleri, yaşam tarzları, sağlık vb. satın alma davranışlarını etkilemektedir. Bu çalışmada gıda seçim tarzlarına göre üç gruba ayrılan tüketiciler incelenmiş ve satın alma davranışlarının birbirlerine göre farklilıklar gösterdiği tespit edilmiştir. Bu nedenle süt ve süt ürünleri üreten firmaların, piyasaya ürün sunarken tüketici tercihlerini ön planda tutmalan, kalite-fiyat dengesini koruyarak, tüketicilerin beklentilerini karşlamaları gerekmektedir. Süt ve süt ürünleri firmaları piyasada diğer markalar ile rekabet edebilmek için düzenli aralıklarla marka değerlendirmesi yapmalıdır. Bu sayede markayı kullanan tüketiciler ile ilişki içerisinde olacakttr. Bununla birlikte, tüketicilere çağr1 merkezi, anket uygulaması, market içi değerlendirme formları gibi uygulamalar ile ürün tanıtımı ve ürün değerlendirmesi yapılması, gerçekçi bir marka değerlendirmesine yardımcı olabilir.

\section{ÇIKAR ÇATIŞMASI BEYANI}

Makale yazarları herhangi bir çıkar çatışması olmadığını beyan etmektedir. 


\section{YAZAR KATKILARI}

Makalenin fikir/kavram, tasarım, denetleme/danışmanlık, yöntem, analiz ve yorum ile makalenin genel düzeni aşamasına katkı yapan yazarlar M. Metin Artukoğlu ve Filiz Kınıklı'dır. Veri toplama, verilerin işlenmesi ve kaynak taraması aşamasında katkı yapan yazarlar, Melike Öncül ve Yusuf Sekman'dır.

\section{KAYNAKLAR}

Açıkgözoğlu, S. (2006). Ürünlerde son kullanma tarihinin tüketicilerce algılanmasına yönelik bir araştrma. Afyonkarahisar Kocatepe Üniversitesi Sosyal Bilimler Enstitüsü Yüksek Lisans Tezi, Afyon, Türkiye, 63s.

Akagün Ergin, E., Özdemir Akbay, H. (2011). Giyim ve gida ürünleri kategorilerinde tüketicilerin plansız satın alma davranışları üzerine bir araşturma. Afyon Kocatepe Üniversitesi İ̈BF Dergisi 13(2): 275-292.

Akbay, C., Tiryaki, Y. G. (2008). Unpacked and packed fluid milk consumption patterns and preferences in Turkey. Agricultural Economics, 38(1): 9-20.

Andiç, S., Şahin, K., Koç, Ş. (2002). Süt tüketim yapıs1: Van ili kentsel alan örneği. Yüzüncü Yul Üniversitesi Ziraat Fakültesi Tarm Bilimleri Dergisi,12(2): 33-38.

Aybek, E. (2011). Kahramanmaraş ili kentsel alanda tüketicilerin süt ve süt ürünleri tüketim ve tercihleri. Kahramanmaraş Sütçü İmam Üniversitesi Fen Bilimleri Enstitüsü Tarım Ekonomisi Anabilim Dalı Yüksek Lisans Tezi, Kahramanmaraş, Türkiye, $60 \mathrm{~s}$.

Çelik, M. (2002). Bat Akdeniz Bölgesinde süt ve süt ürünleri sektörünün stratejik durum analizi ve gelişme olanaklant. Akdeniz IİBF Dergisi, 2(4): 4383.

Çetinkaya, A. (2010). Kafkas üniversitesi öğrencilerinin içme sütü ve süt ürünlerini tüketim alışkanlıklarının belirlenmesi. Atatürk Üniversitesi Vet. Bil. Derg. 5 (2): 73-84.

Demircan, V., Örmeci M. C.., Kizilyar, G. (2011). Isparta ilinde ailelerin ambalajlı ve açı süt tüketim alışkanlıklarının karşılaştırmalı olarak incelenmesi.
Süleyman Demirel Üniversitesi Ziraat Fakültesi Dergisi 6 (2): 39-47.

Dikmen, D., İnan Eroğlu, E., Göktaş, Z., Barut Uyar, B., Karabulut, E. (2016). Validation of Turkish version of the food choice questionnaire. Food Quality and Preference 52: 81-86, doi: 10.1016/j.foodqual.2016.03.016.

Gök, B., Salkın, M., Kenanoğlu Bektaş, Z., Kınıklı, F. (2017). Tüketicilerin süt ve süt ürünler satın alma tercihinde ambalajin etkisi: İzmir ili örneği. Tarm Ekonomisi Dergisi 23 (2): 241-253.

Hair, J.F., Black, W.C., Babin, B.J., Anderson, R.E. (2010). Multivariate Data Analysis. 7th ed. New Jersey: Prentice Hall, the USA.

Karakaya, E., Akbay, C. (2013). İstanbul ilinde tüketicilerin süt ve süt ürünleri tüketim alışkanlıkları. Uludağ Üniversitesi Ziraat Fakültesi Dergisi, 27(1): 65-77.

Malhotra, N.K. (2010). Marketing Research. An Applied Orientation, 6th ed. New Jersey: Pearson.

Newbold, P. (1995). Statistics for Business and Economics. 4th ed. Prentice Hall, New Jersey, 867 s.

Onurlubaş, E., Çakırlar, H. (2016). Tüketicilerin süt ve süt ürünleri tüketimini etkileyen faktörlerin belirlenmesi üzerine bir araştırma. Cankern Karatekin Üniversitesi Sosyal Bilimler Enstitïsü Dergisi 7(1): 217-242.

Örmeci Kart, M. Ç., Demircan V. (2014). Dünyada ve Türkiye'de süt ve süt ürünleri üretimi, tüketimi ve ticaretindeki gelissmeler. Akademik Gida 12 (1):78-96.

Özdamar, K. (2013). Paket Programlar İle Istatistiksel Veri Analizi. Nisan Kitabevi, Eskişehir, Türkiye.

Özel, G. (2008). Tüketicilerin süt tercihinde etkili olan faktörlerin incelenmesine yönelik bir araştırma. Süleyman Demirel Üniversitesi İktisadi ve İdari Bilimler Fakültesi Dergisi, 13(3): 227-240.

Özügüven Tayfun, N. (2015). Market alısverişlerinde plansız satın alma davranışında demografik farklılığ1 belirlemeye yönelik bir araştırma. Selçuk Ün. Sos. Bil. Ens. Der. 34(1): 8794. 
Steptoe, A., Pollard, T.M., Wardle, J. (1995). Development of a measure of the motives underlying the selection of food: the food choice questionnaire. Appetite 25(3):267-284.

Sütütemiz, N., Çiftyıldız S.S., Konuk F.A. (2009). Paketlenmiş süt için ambalaj özelliklerinin algılanan önemi ve satın alma davranışına etkisi: İstanbul ili örneği. Akademik Gıda 7 (6): 18-28.

Tiryaki, Y. G., Akbay, C. (2009). Consumers' fluid milk consumption behaviors in Turkey: An application of multinomial logit model. Quality and Quantity 44(1): 87-98.

USK (2018). Ulusal süt konseyi süt raporu. https://ulusalsutkonseyi.org.tr/wp-
content/uploads/Sut_Raporu_2018_Web_Kapa kli.pdf (Erişim tarihi: 22.12.2019).

Yatağan, F., Yalçın, G., Örmeci Kart, M. Ç., Demircan, V. (2015). Isparta ilinde dondurulmuş gıda ürünlerine yönelik tüketici tercihleri. GID $A$ 40 (2): 77-84.

Yüzbaş1, N., Erkuş, A., Sezgin, E. (1999). Keçiören şefkat mahallesinde çeşitli gelir gruplarındaki ailelerde süt ve süt ürünleri tüketimi. GID A 24(1): 59-67.

Zuckerman, M. (2000), Are you risk taker? Do you drink and drive, gamble, or sleep with strangers? it's not just a behaviour it's personality. Psychology Today 33(6):52-58. 